\title{
PERAN UMAT HINDU DAN KRISTEN DALAM MENJAGA TOLERANSI KEHIDUPAN MASYARAKAT DI KOTA KUPANG NUSA TENGGARA TIMUR
}

\section{THE ROLE OF HINDU AND CHRISTIANS IN KEEPING TOLERANCE OF COMMUNITY LIFE IN KUPANG CITY NUSA TENGGARA TIMUR}

\author{
I Gusti Made Widya Sena \\ Institut Hindu Dharma Negeri Denpasar \\ Jl. Ratna No.51, Tatasan, Denpasar, Bali \\ gusti_sena@yahoo.com
}

Artikel diterima 25 November 2018, diseleksi 19 November 2018, dan disetujui 23 Oktober 2020

\begin{abstract}
Nowadays the tolerance of community life in Kupang City, East Nusa Tenggara Province has been going well. One form of tolerance is reflected in the construction of six houses of worship for adherents of six religions is called the tolerance village in Kelurahan Naibonat, Kupang Timur District. This indicates that the city of Kupang is a city that is friendly to diversity. The role of the community, especially Hindus and Christians in maintaining the tolerance of community life begins with the concept of unity and the motto of the City of Kupang, KASIH (Kupang, Safe, Healthy, Beautiful and Harmonious) which is the background of the realization of community life tolerance in Kupang City, East Nusa Tenggara.
\end{abstract}

The method used is a qualitative research method using a sociological approach. Data collection in this study includes various activities such as: observation, interviews, then data analysis and make recommendations from the results of research conducted. Determination of respondents is done by using purposive sampling technique. In addition to getting a more comprehensive, clear and complete data picture, the researcher uses library research as a method of collecting data to complete the results and search for literature relevant to the object of research.

The results of this study found several supporting factors in maintaining the tolerance of community life in Kupang City including: (1) Geneologists, (2)

HARMONI | Januari - Juni 2020

\begin{abstract}
Abstrak
Dewasa ini, toleransi kehidupan masyarakat di Kota Kupang, Provinsi Nusa Tenggara Timur telah berjalan dengan baik. Salah satu bentuk toleransi ini tercermin dalam pembangunan enam rumah ibadah untuk pemeluk enam agama yang dinamai kampung toleransi di kelurahan Naibonat, kecamatan Kupang Timur. Hal ini menandakan bahwa Kota Kupang adalah kota yang ramah akan perbedaan dan keragaman. Peran masyarakat, khususnya umat Hindu dan Kristen dalam menjaga toleransi kehidupan masyarakat berawal dari konsep kesatuan dan motto Kota Kupang, KASIH (Kupang, Aman, Sehat, Indah dan Harmonis) yang menjadi latar belakang terwujudnya toleransi kehidupan masyarakat di Kota Kupang, Nusa Tenggara Timur.
\end{abstract}

Metode yang digunakan adalah metode penelitian kualitatif dengan menggunakan pendekatan sosiologis. Pengumpulan data dalam penelitian ini meliputiberbagai kegiatan seperti: observasi, wawancara, kemudian analisis data dan membuat rekomendasi dari hasil penelitian yang dilakukan. Penentuan responden dilakukan dengan menggunakan teknik purposive sampling. Selain itu untuk mendapatkan gambaran data yang lebih komprehensif, jelas dan lengkap, maka peneliti menggunakan studi kepustakaan sebagai metode pengumpulan data untuk melengkapi hasil dan mencari literatur yang relevan dengan objek penelitian. 
Role of Religious Leaders, (3) Socially Awareness Communities and (4) Role of Places of Worship. The various forms of participation of the two people, both Hindu and Christian, are shown by: (1) Mutual assistance in maintaining security and order in Kupang City during religious festivals, (2) Improving hospitality, (3) Mutual cooperation and (4) Cooperation of education in strengthening the concept of unity to prevent provocation, radicalism and SARA seeds from entering and destroying the lives of people in Kupang City.

Keywords: Tolerance, Hindus and Christians, Kupang City, Harmony
Hasil penelitian ini menemukan beberapa faktor pendukung dalam menjaga toleransi kehidupan masyarakat di kota Kupang tersebut di antaranya: (1) geneologis, (2) peran pemuka agama, (3) masyarakat yang sadar sosial dan (4) peran tempat ibadah. Berbagai bentuk peran serta kedua umat tersebut, baik Hindu dan Kristen adalah ditunjukkan dengan: (1) saling membantu dalam menjaga keamanan dan ketertiban di kota Kupang saat perayaan hari raya agama, (2) meningkatkan silaturahmi, (3) sikap gotong royong dan (4) kerjasama di bidang pendidikan dalam penguatan konsep kesatuan untuk mencegah provokasi, radikalisme dan benih SARA agar tidak masuk dan menghancurkan kehidupan masyarakat di Kota Kupang.

Kata Kunci : Toleransi, Umat Hindu dan Kristen, Kota Kupang, Harmoni

kekayaan, kekuasaan, dan kenikmatan materi-maka agama hanyalah menjadi lip service belaka dan kehancuran etika, moral, dan spiritual akan semakin besar (Titib, 1995). Hal ini mencerminkan belum dipahaminya ajaran agama secara baik. Penerapan ajaran agama baru berupa tipuan identitas atau baru sebatas ucapan belaka. Untuk itu, sikap empati, keterbukaan, dan toleransi dalam relasi dan interaksi sosial yang hingga kini telah ada sangat perlu ditingkatkan menuju kehidupan yang harmonis, khususnya peran umat Hindu dan Kristen di Kota Kupang, Provinsi Nusa Tenggara Timur.

Tanggal 21 Mei 2015, Wakil Ketua MPR RI Hidayat Nur Wahid berpandangan bahwa Kota Kupang menjadi salah satu kota yang tampak paling menjaga toleransi antarumat beragama di Nusa Tenggara Timur. "Kupang adalah potret Indonesia kecil," beragam tapi bisa menjaga toleransi (kompas.com, 7/7/2020). Kini di Kota Kupang telah terbentuk kampung kerukunan, tepatnya pada 14 September 2019, untuk mewujudkan toleransi di kota tersebut. Pemerintah Kota Kupang, Nusa Tenggara Timur, telah menetapkan 
Kelurahan Fatubesi, Kecamatan Kota Lama sebagai kampung kerukunan hidup beragama. Kelurahan Fatubesi dipilih karena jumlah penduduknya padat dengan beranekaragam suku, budaya, dan agama namun mereka hidup rukun, aman, dan damai. Pembentukan kampung kerukunan ini diharapkan masyarakat Kota Kupang dapat meningkatkan sikap toleransi dan tolong menolong antarsesama. Potensi konflik dalam masyarakat yang heterogen diharapkan tidak ditemukan. (mediaindonesia.com, 7/7/2020).

Berdasarkan data survei indeks Kerukunan Umat Beragama (KUB) tahun 2019 oleh Puslitbang Bimas Agama dan Layanan Keagamaan Badan Litbang dan Diklat Kemenag, Provinsi Nusa Tenggara Timur memiliki nilai toleransi tertinggi kedua di Indonesia. Provinsi NTT memiliki skor $(81,1)$ selisih 1 poin dari Papua Barat yang berada di urutan pertama. Pelaksanaan survei dari 16 Mei-19 Mei 2019 dan 18-24 Juni 2019, terdapat jumlah responden 13.600 orang dari 136 kabupaten/kota yang tersebar di 34 provinsi Indonesia. Metode survei menggunakan penarikan sampel secara acak berjenjang dan margin of error kurang lebih 4,8 persen. Ada tiga hal yang disoroti dalam survei tersebut yaitu toleransi, kesetaraan, dan kerja sama antarumat beragama (tirto.id, 7/7/2020).

Berdasarkan data di atas, warga Kota Kupang khususnya dan Provinsi Nusa Tenggara Timur sebenarnya berpotensi hidup harmonis, penuh dengan toleransi, kesetaraan, dan kerja sama walaupun masyarakatnya heterogen dan multikultural. Ini menarik bagi peneliti untuk mengetahui sejauh mana pola interaksi, faktor-faktor pendukung toleransi kehidupan masyarakat di Kota Kupang, dan peran umat Hindu dan Kristen dalam menjaga toleransi kehidupan masyarakat di Kota Kupang, Provinsi Nusa Tenggara Timur.

\section{METODE PENELITIAN}

Penelitian ini menggunakan metode kualitatif dengan pendekatan sosiologis, yakni penelitian yang diangkat dari realitas sosial. Oleh karena itu, bersifat sentral bagi pemahaman sosiologis pada umumnya. Pendekatan sosiologis di sini berusaha menemukan data yang lebih komprehensif dan valid tentang peran umat Hindu dan Kristen dalam menjaga toleransi kehidupan masyarakat di Kota Kupang, Nusa Tenggara Timur.

Penelitian ini difokuskan di Kota Kupang, Nusa Tenggara Timur. Kota Kupang dipilih sebagai lokasi penelitian, pertama karena di daerah tersebut terdapat agama Hindu dan juga merupakan kantong umat Kristen yang cukup besar jika dibandingkan dengan daerah lain di Indonesia; kedua karena kota tersebut menjadi pusat berbagai aktivitas sosial, ekonomi, budaya, politik, dan pertemuan semua etnis dan agama di Nusa Tenggara Timur; ketiga karena gesekan dan persaingan sosial sangat mungkin terjadi di daerah heterogen seperti ini.

Penelitian ini menggunakan metode kualitatif. Suprayogo (2003) menguraikan bahwa penelitian kualitatif bertujuan untuk memahami dunia makna yang disimbolkan dalam perilaku masyarakat menurut perspektif masyarakat itu sendiri. Penelitian ini tergolong ke dalam penelitian lapangan (field research) yakni penelitian yang langsung dilakukan di lapangan dengan menggunakan bantuan responden.

Pengumpulan data dalam penelitian ini meliputi berbagai kegiatan seperti survei ke lokasi penelitian, mengidentifikasi masalah, mengumpulkan data, studi kepustakaan, analisis data, dan 
kemudian membuat rekomendasi dari hasil penelitian yang dilakukan. Pertama-tama mengidentifikasi masalah yang menjadi objek penelitian dan mengumpulkan data melalui observasi langsung ke lokasi penelitian dengan melakukan wawancara mendalam (indept interview) secara langsung untuk mendapatkan data kualitatif dari informan kunci yang memiliki pengetahuan mendalam tentang objek penelitian serta menyaring data yang berhubungan dengan objek penelitian.

Penentuan responden dilakukan dengan menggunakan teknik purposive sampling. Teknik ini digunakan dalam mengambil sampel yang disesuaikan dengan tujuan penelitian. Dengan kata lain, unit sampel yang dihubungi disesuaikan dengan kriteria-kriteria tertentu yang ditetapkan berdasarkan penelitian (Nawawi, 2007).

Peneliti dalam hal ini mengklasifikasi objek yang diwawancarai berdasarkan kelompok agama (Hindu dan Kristen), golongan umur, pekerjaan, status sosial, dan ketokohannya di masyarakat. Pengelompokan tersebut untuk mendapatkan keterwakilan situasi sebenarnya dari keadaan objek penelitian. Golongan umur informan menggambarkan situasi lapangan yang sebenarnya, terutama adanya perbedaan dan persamaan perspektif dari objek penelitian terhadap eksistensi Hindu dan Kristen di kota Kupang, Nusa Tenggara Timur. Kemapanan hidup yang dilihat dari jenis pekerjaan dan status sosial (ketokohannya) di masyarakat akan memengaruhi pandangan dan pemikiran informan tentang keberadaan dua komunitas ini. Peran tokoh kedua komunitas dipandang sentral, karena dari mereka inilah nilai-nilai toleransi terus diwacanakan sepanjang zaman. Adapun responden yang diwawancarai antara lain: Kepala Bidang Kesatuan Bangsa Provinsi NTT, Ketua PHDI NTT, Wakil Ketua PHDI NTT, Ketua PHDI Kota Kupang, Ketua FKUB Kota Kupang, Ketua Forum Intern Kristen, Kepala Departemen Agama Kota Kupang, Bagian Kemitraan Sinode, Penyelenggara Bimas Hindu Kota Kupang, Pendeta, Ketua Pemuda Oikumene, dan masyarakat.

Untuk memperkuat analisis dan hasil temuan penelitian ini, selain menggunakan teknik pengumpulan data purposive sampling, metode pengumpulan data lainnya adalah studi kepustakaan. Studi kepustakaan dilakukan untuk mencari literatur yang berhubungan dengan objek penelitian. Untuk mendapatkan gambaran data yang lebih komprehensif, jelas, dan lengkap, peneliti mengumpulkan data dari berbagai sumber yang relevan seperti penelitian, artikel jurnal ilmiah, buku, dan lainnya yang menunjang penelitian ini.

\section{PEMBAHASAN}

\section{Sekilas tentang Sejarah Kota Kupang, Propinsi Nusa Tenggara Timur}

Berdasarkan registrasi penduduk tahun 2006, jumlah penduduk meliputi empat kecamatan, yakni Kecamatan Alak, Kecamatan Kelapa Lima, Kecamatan Maulafa, dan Kecamatan Oebobo, sebanyak 275.66 orang dengan total luas wilayah $180,27 \mathrm{~km}^{2}$, yang memeluk lima agama dan lainnya seperti tabel 1 di bawah ini. 


\begin{tabular}{|c|c|c|c|c|c|}
\hline \multirow{2}{*}{ NO } & \multirow{2}{*}{ Kecamatan } & \multicolumn{2}{|c|}{ Banyaknya Penduduk } & \multirow{2}{*}{ Jumlah } & \multirow{2}{*}{$\begin{array}{c}\text { Luas Wilayah } \\
\left(\mathbf{k m}^{2}\right)\end{array}$} \\
\hline & & Laki & Perempuan & & \\
\hline 1 & Alak & 22.312 & 21.161 & 43.473 & 86,91 \\
\hline 2 & Maulafa & 27.340 & 26.634 & 53.974 & 54,80 \\
\hline 3 & Oebobo & 51.512 & 54.370 & 105.882 & 20,32 \\
\hline 4 & Kelapa Lima & 36.796 & 34.941 & 71.737 & 18,24 \\
\hline & Jumlah & 137.960 & 137.106 & 275.066 & 180,27 \\
\hline
\end{tabular}

Sumber: kotakupang.co.id, 20/06/2008

Tabel di atas menunjukkan bahwa Kecamatan Oebobo merupakan kecamatan yang padat penduduknya dibandingkan dengan tiga kecamatan lainnya seperti Kecamatan Kelapa Lima, Kecamatan Maulafa dan Kecamatan Alak. Selain itu, berdasarkan registrasi penduduk 2006 di atas, selisih jumlah penduduk pria sangat kecil dengan jumlah penduduk perempuan. Hanya berbeda 854 orang. Hal ini menunjukkan bahwa penduduk pria lebih banyak
854 orang dibandingkan penduduk perempuan.

Berdasarkan agama, wilayah Kota Kupang tergolong masyarakat heterogen. Terbuktiada lima agamayang berkembang di wilayah tersebut, termasuk juga masih terdapat masyarakat yang menganut kepercayaan dari nenek moyang mereka, seperti animisme dan dinamisme. Jumlah penduduk berdasarkan agama dapat dilihat pada tabel 2 sebagai berikut.

\begin{tabular}{|c|l|c|c|}
\hline NO & \multicolumn{1}{|c|}{ AGAMA } & KOTA KUPANG & TEMPAT IBADAH \\
\hline 1 & Islam/Moslem & 38.975 & 42 \\
\hline 2 & Katolik/Catholik & 62.915 & 176 \\
\hline 3 & Kristen/Christian & 169.951 & 23 \\
\hline 4 & Hindu/Hinduism & 2.713 & 4 \\
\hline 5 & Buddha/Buddhism & 390 & - \\
\hline 6 & Lainnya/Others & 122 & 1 \\
\hline & Jumlah & 275.066 & 246 \\
\hline
\end{tabular}

Sumber: kotakupang.co.id, 20/06/2008

Keterangan: Tabel di atas menunjukkan bahwa agama diyakini mayoritas masyarakat Kota Kupang adalah Kristen (169.951), menyusul agama Katolik, Islam, Hindu, Buddha, dan lainnya sebagai bentuk aliran kepercayaan.

Seperti dua sisi mata uang logam, beragamnya jumlah agama di Kota Kupang dapat mengantarkan kehidupan masyarakat pada dua sisi kehidupan: kehidupan harmonis dan kehidupan intoleran. Menurut Baidhaway (2014), intoleransi agama adalah keengganan untuk mengenali keyakinan orang lain, agama, pendapat, dan praktik mereka, termasuk mengekspresikan ketakutan dan kebencian terhadap orang-orang dari afiliasi agama yang berbeda.

Dewasa ini, interaksi sosial beragama yang terjadi pada masyarakat di Kota Kupang telah berjalan dengan baik. Para pemeluk agama di Kota Kupang menyadari eksistensinya sebagai masyarakat multikultural yang beragam. Halini diperkuatdengankesadaran bahwa 
seluruh masyarakat di Kota Kupang memiliki persamaan hakiki, yakni semua manusia adalah bersaudara dan berasal dari satu Tuhan. Sikap empati, toleransi, damai, akulturasi, saling menerima, dan menghargai perbedaan satu sama lain pada akhirnya berbuah kehidupan yang kondusif bagi masyarakat yang heterogen untuk bermukim di Kota Kupang. Walaupun pada 1998 lalu sempat terjadi konflik yang berbau SARA, namun seiring dengan meningkatnya kesadaran masyarakat terhadap wujud kehidupan yang penuh kedamaian dan toleransi telah mengantarkan masyarakat di Kota Kupang menuju kehidupan yang penuh kasih.

Hal ini ditandai dengan penerapan sikap toleransi yang dapat ditemui di berbagai lingkup kehidupan bermasyarakat. Seperti sikap saling menghargai, tolong-menolong, dan empati dalam mewujudkan interaksi sosial yang harmonis. Penguatan konsep kesatuan di Kota Kupang tentu tidak dapat lepas dari penerapan toleransi sebagai pedoman masyarakat kota Kupang yang multikultural dalam melaksanakan aktivitas sehari-harinya. Tanpa ada toleransi dalam kehidupan masyarakat, ketenangan dan kedamaian hidup hanya berupa impian belaka. Meskipun sikap toleran merupakan pembawaan manusia, beberapa faktor internal dalam diri manusia lainnya seperti sikap egois, kecurigaan, dan iri hati menjadi bahaya laten yang akan menyebabkan intoleransi kehidupan masyarakat.

Dengan moto KASIH (Kupang, Aman, Sehat, Indah, dan Harmonis) merupakan dasar bagi penguatan kesatuan di kota Kupang. Motto ini merupakan dasar bagi masyarakat di Kota Kupang dalam melakukan aktivitasnya sehari-hari. Singkatan dari $\mathrm{KASIH}$ adalah $\mathrm{K}=$ Kupang merupakan Kotamadya sekaligus ibu kota provinsi
Nusa Tenggara Timur, $A=$ Aman mencirikan bahwa di Kota Kupang selalu aman, tertib, dan masyarakat memiliki kebebasan dalam berpendapat, $\mathrm{S}=$ Sehat menunjukkan bahwa Kota Kupang sehat lahir dan batin dengan selalu didukung oleh pemerintah dan seluruh elemen masyarakat, I= Indah panorama dan wisatanya serta $\mathrm{H}=$ Harmonis kehidupan masyarakat di kota Kupang.

Kota Kupang memiliki kondisi geografis yang tropis dan kering, serta dipengaruhi oleh angin dan dikategorikan sebagai daerah yang semi arid karena curah hujan yang relatif rendah, maka mata pencaharian penduduknya cukup beragam. Selain wiraswasta, pegawai negeri, bertani, beternak, dan nelayan merupakan mata pencaharian yang dominan di kota tersebut. Kehidupan pertanian sangat dipengaruhi oleh curah hujan yang cukup. Cocok tanam, khususnya padi, dilaksanakan sekali dalam setahun, yakni pada musim penghujan, sedangkan tanaman lainnya seperti jagung, umi-umbian, dan kacang dapat dilakukan setiap saat.

Selain itu, peternakan di Kota Kupang juga cukup beragam, di antaranya sapi, kerbau, kambing, babi, dan yang paling terkenal adalah kuda yang dipelihara dengan baik oleh masyarakat setempat. Di Kota Kupang mata pencaharian nelayan juga meningkat, karena letak wilayahnya sangat dekat dengan garis pantai. Berbagai jenis ikan, rumput laut, dan mutiara dapat ditemukan di daerah ini.

Tingkat pendidikan di Kota Kupang cukup maju. Hal ini terlihat dari sarana dan prasarana pendidikannya. Di empat kecamatan Kota Kupang telah tersedia sekolah dasar, sekolah menengah pertama, sekolah menengah umum, dan sekolah menengah kejuruan serta guru yang memadai seperti tabel 3 di bawah ini. 


\begin{tabular}{|l|c|c|c|c|c|c|c|c|}
\hline \multicolumn{5}{|c|}{ KECAMATAN } & \multicolumn{4}{c|}{ GURU } \\
\hline & ALAK & MAULAFA & OEBOBO & $\begin{array}{c}\text { KELAPA } \\
\text { LIMA }\end{array}$ & ALAK & MAULAFA & OEBOBO & $\begin{array}{c}\text { KELAPA } \\
\text { LIMA }\end{array}$ \\
\hline SD & 20 & 22 & 42 & 37 & 303 & 331 & 403 & 506 \\
\hline SMP & 5 & 9 & 15 & 12 & 176 & 208 & 315 & 283 \\
\hline SMU & 2 & 5 & 11 & 5 & 25 & 116 & 205 & 159 \\
\hline SMK & - & - & 10 & 7 & - & - & 292 & 230 \\
\hline
\end{tabular}

Sumber: kotakupang.co.id, 20/06/2008

Selain itu, pada pendidikan tingkat lanjut/perguruan tinggi, di kota Kupang telah tersedia 19 universitas/sekolah tinggi/akademik untuk meningkatkan kualitas pendidikan masyarakat Kota Kupang, juga dari daerah lainnya, baik dari daerah Nusa Tenggara Timur maupun kawasan di Indonesia.

\begin{tabular}{|c|c|c|c|c|c|c|}
\hline \multirow[b]{2}{*}{ No } & \multirow[b]{2}{*}{ Nama Perguruan Tinggi } & \multirow[b]{2}{*}{ Fakultas } & \multirow[b]{2}{*}{ Jurusan } & \multirow[b]{2}{*}{ Mahasiswa } & \multicolumn{2}{|c|}{ Dosen } \\
\hline & & & & & Tetap & $\begin{array}{l}\text { Tidak } \\
\text { Tetap }\end{array}$ \\
\hline 1 & Undana & 7 & 38 & 10.143 & 832 & 180 \\
\hline 2 & Unwira & 7 & 22 & 3.057 & 177 & 65 \\
\hline 3 & UKAW & 6 & 10 & 6.018 & 120 & 41 \\
\hline 4 & Univ. Muhammadiyah & 5 & 11 & 1.696 & 61 & 50 \\
\hline 5 & STIM & - & 1 & 611 & 8 & 24 \\
\hline 6 & Univ. PGRI & 5 & 12 & 3.433 & 39 & 127 \\
\hline 7 & Akademi Teknik & - & 2 & 293 & 20 & 20 \\
\hline 8 & STIE Oemathonis & - & 3 & 425 & 19 & 17 \\
\hline 9 & Akademi Pekerjaan Sosial & - & 1 & 85 & 6 & 15 \\
\hline 10 & AKUB Efata & - & 1 & 198 & 9 & 12 \\
\hline 11 & STIBA Mentari & - & 1 & 117 & 7 & 11 \\
\hline 12 & $\begin{array}{l}\text { STIBA Cakrawala } \\
\text { Nusantara } \\
\end{array}$ & 1 & 1 & 227 & 11 & 13 \\
\hline 13 & STIKOM Uyelindo & - & 2 & 1.024 & 15 & 18 \\
\hline 14 & Poltekes & - & 8 & 1.973 & 139 & 112 \\
\hline 15 & $\begin{array}{l}\text { AKOP Indonesia Ratu } \\
\text { Jelita }\end{array}$ & - & 1 & 179 & 3 & 10 \\
\hline 16 & AKPAR & 1 & 2 & 137 & 18 & 17 \\
\hline 17 & Poltek Undana & 1 & 4 & 942 & 158 & 14 \\
\hline 18 & Poltek Pertanian & 1 & 3 & 491 & 126 & 2 \\
\hline 19 & Poltek Negeri & - & 4 & 942 & 158 & 14 \\
\hline
\end{tabular}

Tabel 4

Sumber: kotakupang.co.id, 20/06/2008

Faktor Pendukung dalam Menjaga Toleransi Umat Beragama

Dalam mengembangkan toleransi kehidupan masyarakat di Kota Kupang tentunya tidak dapat lepas dari peran serta berbagai faktor pendukung. Faktor- faktor pendukung tersebut di antaranya: (1) geneologis, (2) peran pemuka agama, (3) masyarakat yang sadar sosial dan, (4) peran tempat ibadah. Penjelasan keempat faktor pendukungnya adalah sebagai berikut. 


\section{1) Genealogis}

Faktor pendukung dalam menjaga dan mengembangkan toleransi kehidupan masyarakat di Kota Kupang, Nusa Tenggara Timur, terwujud dalam intern agama dan antara agama yang satu dengan lainnya memiliki hubungan persaudaraan (genealogis). Hubungan persaudaraan ini akan membantu masyarakat dalam meningkatkan hubungan simbiosis mutualismenya di bidang ekonomi, pendidikan, budaya, dan lainnya. Hubungan persaudaraan ini menjadi dasar hubungan intern agama dan antaragama dengan mengedepankan persamaan di balik keanekaragaman identitas di dalam masyarakat. Dengan begitu, kehidupan masyarakat akan dijauhkan dari sikap negatif, seperti mudah terprovokasi, radikalisme, dan tindak ujaran kebencian (hate speech).

Rosyid (2013:58) menguraikan ada beberapa dampak yang ditimbulkan dari genealogis ini, yakni (1) pada akhirnya lebih mengedepankan ikatan persaudaraan yang berimbas saling memahami perbedaan agama dan perbedaan aliran kepercayaan, (2) bila muncul benih-benih konflik berbasis agama, peran orang tua atau sesepuh dalam keluarga berperan sebagai mediator, (3) antar pemeluk agama dan atau intern agama yang berbeda aliran terjadinya mitra kerja sebagai simbol dari simbiosis mutualisme dan (4) mengedepankan persamaan kebutuhan dan menafikan konflik yang diakibatkan oleh perbedaan keyakinan dan agama.

Tantra (2017:180) menguraikan bahwa hal ini tentunya dapat diperkuat oleh seluruh komponen dengan melalukan intropeksi diri. Intropeksi diri dapat dilakukan dengan cara: (1) pertama selalu sadar untuk menciptakan muatan positif dalam pikiran dan (2) selalu sadar untuk membersihkan pikiran dari muatan negatif. Sikap selalu mawas diri inilah, salah satunya didasarkan pada genealogis atau hubungan persaudaraan yang menjadi dasar dalam menjaga toleransi kehidupan masyarakat di Kota Kupang, Nusa Tenggara Timur.

\section{2) Peran Pemuka Agama}

Pemuka agama adalah tokoh komunitas umat beragama, baik yang memimpin ormas keagamaan maupun yang tidak memimpin ormas keagamaan, yang diakui dan atau dihormati oleh masyarakat setempat sebagai panutan (Tim, 2006). Pemuka agama merupakan tokoh dalam memberikan pembinaan dan memberikan kesejukan bagi umatnya. Selain itu, peran pemuka atau tokoh agama adalah menjadi teman yang menerima usul dari masyarakat dan kemudian menjadi penyambung lidah intern umat, antara umat, dan antarumat dengan pemerintah.

Sebagai tokoh sentral dalam menjaga toleransi kehidupan masyarakat di Kota Kupang, pemuka agama akan menyerap berbagai aspirasi yang diterima dari masyarakat dan kemudian diteruskan dalam dialog antarumat beragama yang difasilitasi oleh pemerintah, kemudian hasil dari dialog antarumat beragama tersebut disebarluaskan kepada umatnya.

Contohnya, konflik yang berbau SARA terjadi di Kota Kupang pada tanggal 30 Nopember 1998, konflik ini terjadi di antara umat Kristen dan Islam. Akibat konflik horisontal tersebut sejumlah tempat ibadah, lembaga pendidikan, dan kios-toko yang dimiliki masyarakat tidak luput dari pengrusakan dan pembakaran yang dilakukan oleh massa yang tidak bertanggung jawab. Bencana tersebut berawal dari acara perkabungan umat Kristiani se-NTT atas kasus di Ketapang, Jakarta beberapa waktu yang lalu. Acara itu sebenarnya direncanakan berupa doa bersama di masing-masing gereja pada pukul 12.00 WITA. Namun sejak pukul 07.00 Wita, ratusan ribu warga memadati seluruh jalan dan gang di tiap penjuru 
kota. Tiba-tiba, acara perkabungan damai itu berubah menjadi aksi brutal. Aksi brutal ini berawal karena provokasi yang dilakukan oleh sebagian orang yang tidak bertanggung jawab yang datang dengan menggunakan empat truk dan tiga minibus. Mereka menghasut massa dengan isu pembakaran gereja Protestan Ketapang dan gereja Kristus Raja Kupang.

Kerusuhan yang bernuansa SARA itu telah mengakibatkan berbagai dampak fisik, psikologis, sosial, dan ekonomi yang luas dan menimbulkan trauma yang mendalam bagi masyarakat Kota Kupang. Perpecahan ini tentunya dapat mengakibatkan intoleransi yang dapat memberikan teror dan mengancam keharmonisan kehidupan masyarakat di Kota Kupang. Untuk itulah peran pemuka agama disini sangat sentral di dalam menjaga kerukunan dan toleransi yang telah terbina sampai saat ini, khususnya melalui wadah Forum Kerukunan Umat Beragama (FKUB) yang dibentuk oleh masyarakat dan difasilitasi oleh pemerintah Daerah/ Kabupaten/ Kota/ Provinsi bersama Kementerian Agama sesuai Peraturan Bersama Menteri Agama dan Menteri Dalam Negeri Nomor: 9 Tahun 2006 dan Nomor: 8 Tahun 2006 dibentuk dalam rangka membangun, memelihara, dan memberdayakan umat beragama untuk kerukunan dan kesejahteraan.

Di Kota Kupang, peran pemuka agama adalah memberikan nasihat, anjuran dan larangan bagi umatnya masing-masing dalam menyikapi berbagai fenomena sosial. Untuk itu, pemuka agama selalu mengajak masyarakat di Kota Kupang untuk selalu arif dan tenang dalam menghadapi berbagai permasalahan sosial yang terjadi. Minimal meminimalisir konflik sosial dari berbagai hoaks dan ujaran kebencian yang dilakukan oleh provokator melalui FKUB.
Itu mengapa peran pemuka agama di Kota Kupang merupakan salah satu faktor yang penting dalam menjaga toleransi kehidupan masyarakat, karena melalui pembinaan pemuka agama pada para umatnya inilah maka kondisi psikis umat dapat tenang dan seimbang. Dengan fisik yang sehat dan psikis yang tenang maka kesejahteraan masyarakat akan dapat meningkat dan kebahagiaan sosial dapat terwujudkan.

\section{3) Masyarakat yang Sadar Sosial}

Yulianthi (2015:75) menguraikan bahwa masyarakat adalah keseluruhan hubungan-hubungan dalam hidup bersama dan tidak dibatasi oleh lingkungan, bangsa, dan sebagainya atau dengan kata lain kebulatan dari semua perhubungan dalam hidup bermasyarakat. Hubungan ini tentu karena ada bentuk-bentuk aturan hidup, yang bukan disebabkan oleh manusia sebagai perorangan, melainkan oleh unsur-unsur kekuatan lain dalam lingkungan sosial yang merupakan kesatuan. Para ahli seperti Maclver, J.L Gillin dan J.P Gillin sepakat bahwa, adanya saling bergaul dan interaksi karena mempunyai nilai-nilai, normanorma, cara-cara dan prosedur yang merupakan kebutuhan bersama sehingga masyarakat merupakan kesatuan hidup manusia yang berinteraksi menurut sistem adat istiadat tertentu, yang bersifat berkelanjutan dan terikat oleh suatu rasa identitas bersama (Soelaeman, 2005).

Ahmad (2001) menjelaskan bahwa kondisi intoleran dan agresif yang mengarah pada radikalisme dalam keberagamaan fluktuasinya semakin naik. Hal ini dipicu oleh beberapa faktor berikut ini. Pertama, intervensi kekuasaan terhadap model-model dialog keagamaan dengan dalih membina kerukunan umat beragama. Karena intervensi inilah, masing-masing pemeluk agama menjadi kehilangan independensinya untuk menentukan platform mereka, yang 
secara internal sesuai dengan kebutuhan umatnya sendiri dan secara eksternal juga positif bagi sesama umat beragama yang lain. Dalam hal ini elite agama berada dalam posisi dilematis karena dituntut fleksibel bermain di antara interes umat dan kekuasaan.

Kedua, semakin menjamurnya budaya verbalisme. Tampaknya dialog sudah kehilangan wibawanya. Ibarat obat, dialog adalah pil penenang yang hanya memberikan ketenangan sesaat namun tidak mampu menyembuhkan penyakit yang sesungguhnya sampai ke akar-akarnya. Dialog bukan sebagai kebutuhan pembebasan dari sekat-sekat dinding perbedaan agama, melainkan hanya berfungsi sebagai pelipur lara dan cenderung menjadi ritual dan simbolitas.

$\begin{gathered}\text { Ketiga, pendekatan pembinaan } \\ \text { keagamaan yang }\end{gathered}$
kehidupan ara topdown, artinya
menggunakan cara
yang diajak berdialog hanya kaum elite
agama saja. Hal ini merupakan bias dari
ideologi pembangunanisme yang lebih
mengutamakan perubahan dari atas dan
menetes ke bawah (trickle down effect)
daripada perubahan dari bawah ke atas
(buttom up). Keempat, perlu perumusan
kembali konsep dialog yang tidak hanya
linear, tapi harus memperhatikan semua
pihak (multifaset). Kelima, hendaknya
dialog tidak didasarkan pada prinsip
mayoritas dan minoritas, tapi lebih
didasarkan pada kebutuhan dan
kepentingan bersama dalam mencapai
toleransi kehidupan yang harmonis
antarumat beragama dalam satu bingkai
nasionalisme Indonesia.

Bentuk dialog yang terjadi dalam relasi kehidupan masyarakat akan bermuara pada komunikasi lintas budaya sebagai bentuk komunikasi yang berusaha untuk memahami komunikasi di antara anggota masyarakat yang berbeda budayanya, meliputi perilaku komunikasi dari komunikator (proses encoding), makna umum, dan makna khusus dari lambang komunikasi, dan perilaku komunikan atau proses decoding.

Liliwerimendefinisikan komunikasi antar budaya adalah komunikasi antara orang-orang yang berbeda kebudayaan, misalnya antar suku bangsa, antar etnik dan ras, antar kelas sosial (Liliweri, 2003). Selain itu Dood (dalam Liliweri 2003), menguraikan bahwa komunikasi antar budaya meliputi komunikasi yang melibatkan peserta komunikasi yang mewakili pribadi, antar pribadi, dan kelompok, dengan tekanan pada perbedaan latar belakang kebudayaan yang mempengaruhi perilaku komunikasi para peserta.

Peran masyarakat di Kota Kupang dengan menggunakan dialog komunikasi lintas budaya di sini sangat penting dan sedapat mungkin dilakukan secara intens dalam menjaga toleransi dan menciptakan iklim kehidupan yang kondusif. Sikap selalu waspada dan tidak mudah terpengaruh terhadap isuisu yang berbau SARA sangat perlu dikedepankan dalam menjaga toleransi kehidupan masyarakat di kota Kupang, provinsi Nusa Tenggara Timur.

Masyarakat Kota Kupang adalah masyarakat yang plural. Memiliki ragam budaya, bahasa, suku, dan agama. Untuk itu sangat mungkin berbagai kasus intolerasi dan disharmonisasi muncul di daerah yang heterogen seperti ini. Peran masyarakat dalam menjaga dan melindungi satu sama lainnya, minimal dalam kehidupan keluarga dan meningkat ke skala yang lebih luas seperti kehidupan masyarakat sangat penting dikedepankan. Kesadaran sosial menjadi unsur yang penting dalam mewujudkan toleransi.

Kesadaran sosial tidak hanya bermakna memiliki empati terhadap seseorang dan lingkungan sekitarnya saja, namun bentuk yang lebih nyata dari implementasi kesadaran sosial 
adalah memberikan pelayanan pada kemanusiaan dengan melayani masyarakat lainnya, sekalipun itu berbeda keyakinan, suku dan budayanya. Menurut Maslikhah (dalam Tim, 2018), kesadaran multikultural ini penting dalam pergaulan antar budaya yang perlu sikap saling menghormati satu sama lain. Kesadaran multikultural juga menjunjung tinggi pentingnya sikap dan perilaku toleransi dalam kehidupan bangsa Indonesia yang multi etnik ini. Sikap toleransi ini penting dalam membina kehidupan bangsa yang multikultural. Keberagaman budaya masyarakat nusantara ini merupakan konsekuensi keragaman budaya, etnis, suku, dan aliran atau agama.

Kesadaran ini terlihat seperti suasana kesejukan dan kedamaian yang diperlihatkan oleh keluarga Kristiani dan Hindu saat kerusuhan pada tahun 1998 itu terjadi di Kota Kupang. Mereka memberikan pertolongan dan tempat tinggal sementara di rumahnya bagi keluarga muslim yang memiliki usaha toko sembako sampai keadaan kembali kondusif. Rasa trauma dan khawatir terhadap keadaan saat itu telah menghilangkan harapan saudara muslim untuk bisa menyelamatkan nyawa dan harta kekayaannya. Baik keluarga Kristen maupun Hindu segera mendatangi rumah tetangganya yang muslim dan mengajak mereka untuk segera mengemasi barang berharganya dan mengajaknya untuk tinggal di rumahnya.

Kesadaran sosial yang dimiliki masyarakat seperti ini menandakan bahwa berbagai dinding dan sekat pemisah di antara manusia telah luluh tergantikan oleh rasa kasih dan empati. Agama tidak lagi menjadi sebuah simbol pedoman dan penuntun umat, namun lebih dari itu, agama menjadi jalan kasih bagi umat dalam mencapai kebahagiaan dan kedamaian hidup bersama. Berawal dari itu, masyarakat sadar akan hidup bersama sebagai satu saudara, "sebagai kita", bukan sebagai aku, kamu ataupun mereka.

\section{4) Peran Tempat Ibadah}

Tempat Ibadah atau rumah ibadah adalah bangunan yang memiliki ciriciri tertentu yang khusus dipergunakan untuk beribadah bagi para pemeluk masing-masing agama secara permanen, tidak termasuk tempat ibadah keluarga (Tim, 2006).

Di Indonesia fungsi tempat ibadah berperan menjadi tiga fungsi, yakni: fungsi keagamaan, fungsi pendidikan karakter dan fungsi sosial dalam mengatasi konflik. Dalam fungsi keagamaan, berbagai tempat ibadah di Kota Kupang merupakan rumah Tuhan dan tempat untuk beribadah kepadaNya. Tempat ibadah digunakan dalam membangun relasi hubungan religius vertikal dan sakral antara manusia dengan Tuhan.

Di Kota Kupang, fungsi tempat ibadah dalam pendidikan karakter adalah sebagaiwadahdalammentransformasikan pengetahuan dan membuka cakrawala berpikir umat. Ini sangat penting dalam memupuk, membangun dan pada akhirnya membentuk karakter umat menjadi pribadi yang religius, memiliki rasa empati dan toleransi yang tinggi. Karena di dalam tempat ibadah nilainilai religus dan etika dari kitab suci dapat ditransferkan kepada umat melalui khotbah atau dharma wacana yang disampaikan oleh para rohaniawan dan pemuka agama seperti ustad, pandita, pendeta, biksu, romo dan lainnya yang membantu umat untuk kembali pada ajaran-ajaran agama dan memahami ajarannya dengan benar sehingga pada akhirnya dapat menghindari umat dari berbagai tindakan provokasi, hoaks, hate speech, dan radikalisme yang sempit akibat terbatasnya pikiran dan pengetahuan dalam memahami doktrin agama.

Di Kota Kupang, fungsi ketiga tempat ibadah adalah sebagai fungsi sosial 
dan mengatasi konflik tentunya dapat kita perhatikan hingga saat ini tempat ibadah digunakan sebagai wadah oleh umat dalam menjalin dan mengembangkan tali silaturahmi intern umat beragama dan antar umat beragama. Silaturahmi yang terjalin di dalam tempat ibadah tentunya mengembangkan dialog agama, lintas budaya, dan pendidikan. Jika dialogdialog ini dibangun atas dasar saling menghargai, menghormati dan kesadaran universal, maka fungsi sosial tempat ibadah tentunya dapat terwujud dalam mengatasi konflik horisontal. Budiyono (dalam Aijudin, 2017) berpandangan bahwa individu atau komunitas yang berdialog bisa saling belajar antara satu dengan lainnya mengenai pengalaman kehidupan keberagamaan mereka. Melalui dialog akan ada kemungkinan masing-masing peserta dialog untuk mengalami perubahan dalam berinteraksi antara satu dengan lainnya, lebih terbuka terhadap mitra dialognya, atau setidaknya lebih memahami keyakinan, pemikiran, dan persoalan yang dihadapi oleh mitra dialognya (Th.Sumartana, 1993).

Tempat ibadah juga berperan dalam menjaga toleransi kehidupan antarumat beragama, hal ini ditandai dengan adanya kerjasamayangdilakukanolehinternumat beragama, seperti kegiatan kerja bakti mempersiapkan hari raya keagamaan dan melakukan kegiatan intern dalam meningkatkan keimanan pada Tuhan. Selain itu, dalam kehidupan antar umat beragama, tempat ibadah di Kota Kupang merupakan salah satu media dalam menciptakan kehidupan yang harmonis, implementasi dalam kesehariannya seperti mengembangkan dialog dalam mengatasi konflik, melakukan kerja bakti pembangunan tempat ibadah, menjaga tempat ibadah pada saat pelaksanaan hari raya keagamaan umat lain, melakukan seminar, lokakarya dan lainnya. Seperti saat perayaan Hari Raya Natal di gereja, maka para pemuda Hindu yang tergabung dalam Peradah (Perhimpunan Pemuda Hindu) menjaga keamanan dan ketertiban di sekitar gereja sehingga umat Kristiani dapat menjalani ibadahnya dengan nyaman dan khusyuk. Begitu pula sebaliknya, saat perayaan hari raya Galungan, pemuda Kristiani sebaliknya menjaga keamanan dan ketertiban di Pura.

\section{Peran Umat Hindu dan Kristen dalam Menjaga Toleransi Kehidupan Masyarakat di Kota Kupang, Nusa Tenggara Timur}

PeranumatHindudanKristendalam menjaga toleransi kehidupan masyarakat di Kota Kupang, Provinsi Nusa Tenggara Timur sangat penting dikedepankan. Upaya penciptaan toleransi beragama di Kota Kupang saat ini telah berjalan dengan baik dalam menciptakan iklim kehidupan masyarakat yang harmonis. Hal ini didasari oleh kesadaran sosial dan sifat empati untuk saling menghargai, menghormati, dan menyebarkan cinta kasih di antara satu dengan lainnya. Peran umat Hindu dan Kristen dalam menjaga toleransi kehidupan masyarakat di Kota Kupang, Nusa Tenggara Timur antara lain ditunjukkan dengan:

Pertama adalah ketika ada perayaan hari raya keagamaan, umat Hindu dan Kristen saling menjaga keamanan dan ketertiban. Ketika ada perayaan Natal dan Paskah maka umat Hindu melalui KMHDI (Kesatuan Mahasiswa Hindu Dharma Indonesia) dan Peradah (Perhimpunan Pemuda Hindu) Kota Kupang ikut menjaga ketertiban dan keamanan gereja. Begitu pula sebaliknya saat umat Hindu sedang beribadah pada saat Hari Raya Galungan, Saraswati, dan hari-hari raya Hindu lainnya, maka pemuda Kristiani secara gantian ikut menjaga keamanan dan ketertiban di lingkungan Pura. 
Kedua, setelah selesai peribadatan di tempat ibadah. Umat Hindu dan Kristen saling mengunjungi untuk menjaga tali silaturahmi dan persaudaraan. Bentuk silaturahmi ini bertujuan untuk menjaga hubungan kekerabatan sebagai simbol persaudaraan kasih yang dilahirkan ke dunia ini. Selain itu praktik saling kunjung-mengunjungi di antara umat Hindu dan Kristen dibangun karena samasama ingin menjaga dan menyebarkan motto kota Kupang sebagai kota KASIH representasi dari Kota Kupang yang aman, sehat, indah, dan harmonis.

Silaturahmi sebagai bentukinteraksi sosial tidak hanya bermanfaat bagi fisik namun juga bagi kesehatan psikis dan peningkatan spritual masyarakat. Manfaat lainnya dari mempraktikkan silaturahmi dalam kehidupan seharihari adalah menjaga kerukunan, meningkatkan rejeki, meningkatkan imun tubuh, menjaga kesehatan psikis, dan menghindari dari prasangka yang buruk.

Ketiga, bentuk peran serta umat Hindu dan Kristen dalam menjaga toleransi kehidupan masyarakat di kota Kupang adalah bergotong royong membangun tempat ibadah. Ketika ada pembangunan Pura Agung Giri Kertha Bhuana di kecamatan Maulafa, umat Kristiani yang tersebar di daerah tersebut baik tua maupun muda secara sukarela ikut bahu membahu membantu dalam pembangunan Pura Agung Giri Kertha Bhuana, baik dengan ikut memberikan bantuan dana maupun tenaga. Tidak hanya dalam membangun tempat ibadah, sikap gotong royong ini juga ditunjukkan dalam hampir setiap kehidupan masyarakat, seperti pada saat pawai paskah dan HUT kota Kupang, maka warga akan bercampur menjadi satu saling menolong satu dengan lainnya. Selain itu, bentuk gotong royong ini juga tercermin saat salah satu umat memiliki kegiatan atau acara pernikahan, maka umat lainnya yang berada di sekitar rumahnya, akangotong royong membantu menyukseskan acara tersebut. Ini menandakan pemahaman umat semakin baik dalam mengimplementasikan nilainilai agamanya masing-masing dalam kehidupan sosial.

Keempat di bidang pendidikan, peran umat Hindu dan Kristen dalam menjaga toleransi masyarakat di Kota Kupang, Nusa Tenggara Timur adalah dengan mengadakan berbagai dialog kerukunan dan pertemuan ilmiah secara berkala, seperti seminar atau workshop bersama. Sering kali utusan dari umat Hindu dan Kristen mengikuti pertemuan ilmiah bersama, mereka akan duduk dan berdialog bersama dengan melepas perbedaan kesukuan dan baju ritual masing-masing. Bagi mereka jalinan silahturahmi itu bukan sebuah simbolis yang sengaja dibuat agar kelihatan manis diluarnya tapi sebaliknya manisnya silaturahmi itu telah ada sejak manusia dilahirkan di dunia ini.

Hingga saat ini, umat Hindu dan Kristen di Kota Kupang, Nusa Tenggara Timur, sudah seperti saudara yang saling mendukung dan bahu-membahu dalam berbagai bidang kehidupan sehari-hari. Nilai-nilai etika Hindu yang dipraktikkan oleh umat, seperti jujur, terbuka, dan kerja keras menjadi panutan bagi umat Kristiani dalam meningkatkan relasi sosial dan menjaga toleransi di Kota Kupang. Begitu pula sebaliknya, sifat kasih universal dari umat Kristiani dijadikan panutan bagi umat Hindu dalam membina relasi yang telah terjalin baik hingga kini. Itu mengapa peran serta umat Hindu dan Kristiani di Kota Kupang, Nusa Tenggara Timur, saling melengkapi satu sama lain.

\section{SIMPULAN}

Peran umat Hindu dan Kristen sangat penting dalam menjaga dan 
mengembangkan toleransi masyarakat di Kota Kupang, Nusa Tenggara Timur. Hingga kini, umat Hindu dan Kristen telah berperan dengan mengimplementasikan ajaran agamanya secara baik demi mewujudkan kehidupan yang harmonis. Faktor-faktor pendukung dalam menjaga toleransi kehidupan masyarakat di Kota Kupang, Nusa Tenggara Timur, tersebut di antaranya: (1) geneologis, (2) peran pemuka agama, (3) masyarakat yang sadar sosial dan, (4) peran tempat ibadah

Berbagai bentuk peran serta kedua umat tersebut, baik Hindu dan Kristen, ditunjukkan dengan: (1) saling membantu dalam menjaga keamanan dan ketertiban di Kota Kupang saat perayaan hari raya agama, (2) meningkatkan silaturahmi, (3) sikap gotong royong, dan (4) kerja sama bidang pendidikan dalam penguatan konsep kesatuan untuk mencegah provokasi, radikalisme, dan benih SARA agar tidak masuk dan menghancurkan kehidupan masyarakat di Kota Kupang.

Toleransi yang berkembang ini tidak hanya menitikberatkan pada kemampuan menjaga kerukunan dan keharmonisan lingkungan, lebih luas dari itu, sikap nyata toleransi ini diwujudkan dalam memandang bahwa semua manusia adalah sama/setara sebagai saudara universal, tidak ada perbedaan di antara satu dengan lainnya. 


\section{DAFTAR ACUAN}

Ahmad, Nur. (2001). Pluralitas Agama: Kerukunan Dalam Keragaman. Jakarta: Kompas.

Aijudin, Anas. (2017). Mengelola Pluralisme Melalui Dialog Antar Agama (Sebuah Tinjauan Teoritik). Jurnal SMART (Studi Masyarakat, Religi dan Tradisi). 3 (1), 119-124.

Baidhway, Z. (2014). Pendidikan Agama Islam Untuk Mempromosikan Perdamaian Dalam Masyarakat Plural. Analisis: Jurnal Studi Keislaman, 14 (2), 289-309.

Liliweri, Alo. (2003). Dasar-dasar Komunikasi Antar Budaya. Yogyakarta: Pustaka Pelajar.

Nawawi, Hadari H. (2007). Metode Penelitian Bidang Sosial. Yogyakarta. Gajah Mada University.

Rosyid, Moh. (2013). Harmoni Kehidupan Sosial Beda Agama Dan Aliran Di Kudus. Jurnal ADDIN, 7 (1), 41-63.

Sumartana, Th. (1993). Menuju Dialog Antar Iman, Dalam Dialog, Kritik dan Identitas Agama. Yogyakarta: Interfidei.

Suprayogo, Iman \& Tobroni. (2001). Metodologi Penelitian Sosial-Agama. Bandung : PT Remaja Rosdakarya.

Soelaeman, M. Munandar. 2005. Ilmu Sosial Dasar: Teori dan Konsep Ilmu Sosial. Bandung: Refika Aditama.

Tantra, Dewa Komang. (2017). Membaca Perubahan Bali. Bali: Wisnu Press.

Titib, I Made. (1995). Ketuhanan Dalam Veda. Denpasar: Manik Geni.

Tim. 2006. Peraturan Bersama Menteri Agama Dan Menteri Dalam Negeri tentang Pedoman Pelaksanaan Tugas Kepala Daerah Dalam Pemeliharaan Kerukunan Umat Beragama, Pemberdayaan Forum Umat Beragama Dan Pendirian Rumah Ibadah. Jakarta: Sekretariat Badan Litbang Dan Diklat.

Yulianthi. (2019). Ilmu Sosial Budaya Dasar. Yogyakarta: Deepublish.

Sumber internet:

Diakses tanggal 20 Juni 2008. http://www/kotakupang.co.id.

Diakses tanggal 7 Juli 2020. https:majalah.tempo.co/read/perilaku/98030/kupang-rusuh.

Diakses tanggal 7 Juli 2020. https://m.mediaindonesia.com/read/detail/harmoni-dikampung-kerukunan-kota-kupang..

DariNTT. Diaksestanggal7 Juli 2020.https://www.google.com/kompas.com/meneladani. kerukunan.beragama.

Diakses tanggal 7 Juli 2020. https://www.google.com/amp.tirto.id/daftar-skor-indekskerukunan-beragama-versi-kemenag-2019, 